Final Progress Report DE-FG02-87ER13766 P.I. B. S. Freiser (deceased) "Reactions of Metal Ions and their Clusters in the Gas Phase using Laser Ionization-Fourier Transform Mass Spectrometry" $4 / 1 / 95-3 / 31 / 99$

Faculty and senior personnel supported

B. S. Freiser, T. Ast, C-Y Lin, Z. Kan

Graduate Students supported
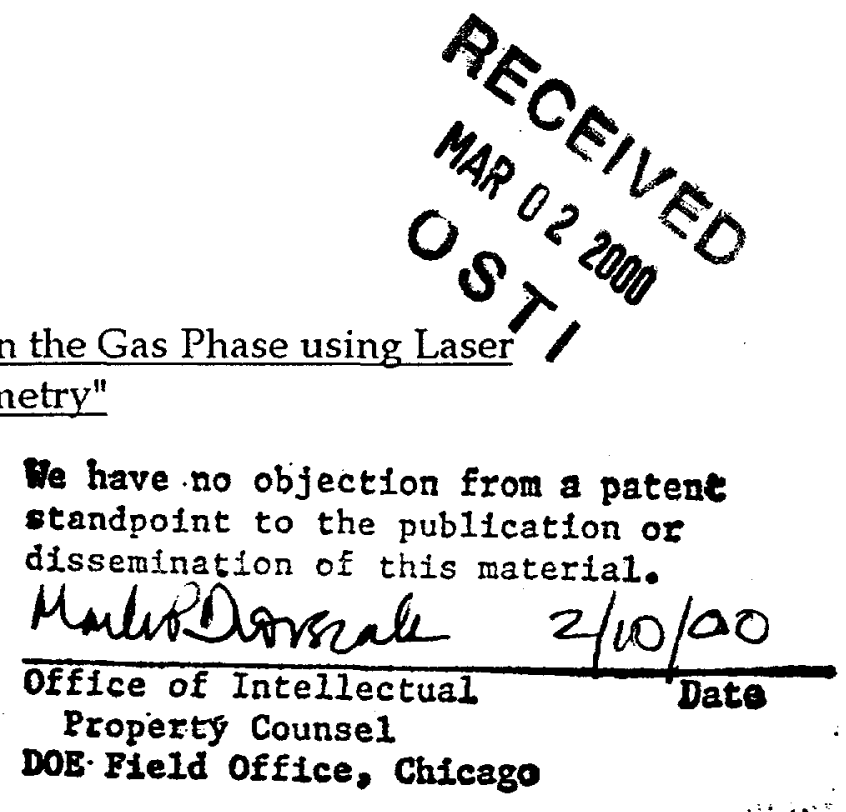

Y-G. Byun, Q. Chen, H. Chen, J. M. Delgado, R. Li, H. Liu, V. K. Nanayakkara, G. E. Patterson

Ph. D. Theses (1998 and 1999)

Quan Chen 5/98 "Applications of Fourier Transform Ion Cyclotron Resonance (FTICR) Mass Spectrometry and Density Functional Theory to the Studies of GasPhase Metal Ion-Ligand Structures and Reactivities"

Ruomei Li 8/99 " Studies of Organometallic Ions in the Gas-Phase by using Fourier Transform Ion Cyclotron Resonance Mass Spectrometry"

Huiping Chen 8/99 " A Gas-Phase Study of the Structure, Reactivity and Thermochemistry of Transition Metal-Ligand Systems by Fourier Transform Ion Cyclotron Resonance Mass Spectrometry and Density Functional Theory"

\title{
Summary of Research Accomplished
}

\section{(a). Overview}

The Freiser group pioneered the study of metal/organic and organometallic ion chemistry in the gas phase. As they frequently pointed out, the importance of this work was not restricted to mass spectrometry, but lay in the insights it provides into chemistry in other environments. A lasting monument to that work is the body of knowledge that now exists on the activation of $\mathrm{C}-\mathrm{H}$ and $\mathrm{C}-\mathrm{C}$ bonds by metal ions. This includes a great deal of predictive mechanistic detail that is now available. Freiser also contributed immensely to the acquisition of thermochemical information in these systems, and the large body of thermochemical data that he assembled, much recorded in his own lab, is being passed on Prof. Peter Armentrout to act as custodian for the interested community. Another major accomplishment was the early appreciation of the need to supplement mass spectrometry experiments by theory and Freiser succeeded in making connections with leading theoreticians 


\section{DISCLAIMER}

This report was prepared as an account of work sponsored by an agency of the United States Government. Neither the United States Government nor any agency thereof, nor any of their employees, make any warranty, express or implied, or assumes any legal liability or responsibility for the accuracy, completeness, or usefulness of any information, apparatus, product, or process disclosed, or represents that its use would not infringe privately owned rights. Reference herein to any specific commercial product, process, or service by trade name, trademark, manufacturer, or otherwise does not necessarily constitute or imply its endorsement, recommendation, or favoring by the United States Government or any agency thereof. The views and opinions of authors expressed herein do not necessarily state or reflect those of the United States Government or any agency thereof. 


\section{DISCLAIMER}

Portions of this document may be illegible in electronic image products. Images are produced from the best available original document. 
and so was instrumental in contributing to the current situation in which ab initio or density functional calculations are a necessary part of studies of metal ion organometallic chemistry. Freiser made important contributions to the instrumentation and methodology of mass spectrometry, especially in ion cyclotron resonance where he did the first collision-induced dissocation experiments and so introduced the MS/MS methodology. He also made important contributions to methods for the creation of metal ions in his thennovel laser based methods of ionization. More recently, his work on metallocarbohedranes, on fullerene metal complexes, on C-F bond activation and numerous other topics stands out.

The gas-phase reactions of a number of ligated metal species have been studied using Fourier transform ion cyclotron resonance mass spectrometry (FTICR-MS), together with density functional theory (DFT) calculations in recent work which is described in more detail in the remainder of this report.

Both experimental and theoretical results indicate that the structure of $\mathrm{MCF}_{3}{ }^{+}(\mathrm{M}=\mathrm{Fe}$, $\mathrm{Co}$ and $\mathrm{Ni})$ corresponds to a $\left[\mathrm{FM}^{+} \cdots \mathrm{F}_{2} \mathrm{C}\right]$ ion-dipole complex with electrostatic bonding between $\mathrm{FM}^{+}$and $\mathrm{CF}_{2}$, involving $\mathrm{C}-\mathrm{F}$ activation. This represents the first case of a gas-phase $\mathrm{C}-\mathrm{F}$ activation by bare cobalt ions. The reaction mechanisms were further investigated by obtaining the potential energy surfaces of $\left[\mathrm{M}^{+}, \mathrm{C}, \mathrm{F}_{3}\right]$ cation systems by density functional calculations. In order to compare the structure and reactivity of the $\mathrm{CF}_{2}$ group on $\mathrm{MCF}_{3}{ }^{+}$, the reactions of fluorinated metal-carbene ions $\mathrm{FeCF}_{2}{ }^{+}$and $\mathrm{CoCF}_{2}{ }^{+}$with selected hydrocarbons are studied. The experimental and theoretical results illustrate that the $\mathrm{CF}_{2}$ ligand on $\mathrm{MCF}_{2}{ }^{+}$is different from that on $\mathrm{FM}^{+}+\ldots \mathrm{F}_{2} \mathrm{C}$ in terms of structure, chemical bonding and reactivity with small hydrocarbons.

The ligand effects of formaldehyde and its sulfur-containing analog, thioformaldehyde, on $\mathrm{Fe}^{+}$were investigated. We found distinct differences between the reactivities of $\mathrm{FeCH}_{2} \mathrm{O}^{+}$and $\mathrm{FeCH}_{2} \mathrm{~S}^{+}$. While $\mathrm{C}-\mathrm{C}$ insertion leading to alkane loss is predominant for the reactions of $\mathrm{FeCH}_{2} \mathrm{O}^{+}$with alkanes, $\mathrm{C}-\mathrm{H}$ insertion is preferred for $\mathrm{FeCH}_{2} \mathrm{~S}^{+} . \mathrm{CH}_{2} \mathrm{O}$ behaves like a spectator ligand. On the other hand, $\mathrm{CH}_{2} \mathrm{~S}$ ligand participates in a rearrangement to form an activated $\mathrm{H}_{2} \mathrm{~S}-\mathrm{Fe}^{+}$-olefin complex. The reaction mechanisms are proposed and theoretical calculations are fully supportive in explaining the different reaction pathways.

The gas-phase $\mathrm{Fe}^{+}$-assisted cycloaddition of cyclopentadiene with small alkenes and alkynes were also studied. $\mathrm{Fe}^{+}$-cyclopentadiene is found to react with ethene, propene, ethyne, propyne and allene to generate Diels-alder reaction products, which further rearrange to $C_{7}-C_{8}$ membered cyclic Fe complex ions. 
The gas-phase chemistry of several other transition metal-ligand systems have also been studied, again using Fourier transform ion cyclotron resonance mass spectrometry and density functional theory. The reactions of $\mathrm{M}^{+}-2,3-$ didehydropyrazine $(\mathrm{M}=\mathrm{Fe}, \mathrm{Co})$ with small alkenes and alkynes were investigated. Overall, $\mathrm{M}^{+}-2,3$-didehydropyrazine has a richer and more complex reactivity than $\mathrm{Fe}^{+}-o$-benzyne with the unsaturated hydrocarbons. Collision induced dissociation and sustained off-resonance irradiation were used to probe the product ion structures for all ion-molecule reactions. Using this information, metal-centered mechanisms were proposed. DFT calculations on $\mathrm{Fe}^{+}-2,3-$ didehydropyrazine suggest a pyrazinometallacyclopropene structure and predict $\mathrm{D}^{\circ}\left(\mathrm{Fe}^{+}-2,3\right.$-didehydropyrazine) to be $87 \pm 10 \mathrm{kcal} / \mathrm{mol}$.

$\beta-\mathrm{H}$ migration from an organic ligand to the transition metal center and the reversed process, insertion of the unsaturated organic ligand into the metalhydrogen bond are ubiquitous processes for organometallic chemistry. $\mathrm{MC}_{2} \mathrm{H}_{3}{ }^{+}$ and $\mathrm{MC}_{2} \mathrm{H}_{5}{ }^{+}(\mathrm{M}=\mathrm{Fe}, \mathrm{Co})$ represent ideal model systems for the gas-phase studies of $\beta-\mathrm{H}$ migration where complexity is minimized while the relevant structural and electronic requirements are preserved. The experimental results indicate $\mathrm{M}\left(\mathrm{C}_{2} \mathrm{H}_{3}\right)^{+} \leftrightarrow \mathrm{HM}\left(\mathrm{C}_{2} \mathrm{H}_{2}\right)^{+}$and $\mathrm{M}\left(\mathrm{C}_{2} \mathrm{H}_{5}\right)^{+} \leftrightarrow \mathrm{HM}\left(\mathrm{C}_{2} \mathrm{H}_{4}\right)^{+}$interconversions are facile processes for activated $\mathrm{MC}_{2} \mathrm{H}_{3}{ }^{+}$and $\mathrm{MC}_{2} \mathrm{H}_{5}{ }^{+}$ions, as predicted by DFT calculations.

$\alpha-\mathrm{H}$ migration for the $\mathrm{MHNO}^{+}(\mathrm{M}=\mathrm{Fe}, \mathrm{Co}$ system was also investigated. Optimized structures and energetics of three $\mathrm{CoHNO}^{+}$isomers were obtained by DFT calculations. $\mathrm{CoHNO}^{+}$reacts with methane by dehydrogenation, an unusual reactivity not observed by many other cobalt complexes. Potential energy surface diagrams and proposed mechanism for selected ion-molecule reactions were presented.

Fourier transform ion cyclotron resonance mass spectrometry combined with laser desorption was also applied to other types of novel organometallic ions in the gas-phase. The polyhydrido trimethylphosphine rhenium complex, $\mathrm{ReH}_{7}\left(\mathrm{Pme}_{3}\right)_{2}$, and fragment ions, $\mathrm{ReH}_{x}\left(\mathrm{Pme}_{3}\right)_{2}+/$, were generated and examined in the mass spectrometer to determine their structures or characters. The ionmolecule reaction results indicate that $\mathrm{ReH}_{7}\left(\mathrm{Pme}_{3}\right)_{2}$ prefers to lose molecular hydrogens, to dimerize and to be attached by the electron rich atom $/ \mathrm{molecule}$ in the gas-phase.

The $\sigma$-bond, $\pi$-bond and $\mathrm{M}=\mathrm{S}, \mathrm{M}=\mathrm{O}, \mathrm{M}=\mathrm{CH}_{2}$ bond containing metalligand ions react with tert-butyl isocyanide to generate different products. The two kinds of imidoly ion/dipole complexes are formed in the initial steps in these reactions based on bond type and bond energy of the metal-ligand 
complexes. Consequently, reaction mechanisms and product distributions depend on the initially-generated imidoly ion/dipole complexes.

The generation and characterization of transition-metal distonic ions, which contain the metal charge site spatially separated from the radical site are reported. The fluorine-substituted metal distonic ion $1 \mathrm{Fe}^{+} \mathrm{C}_{6} \mathrm{~F}_{4}{ }^{*}$ was formed by rearrangement of a conventional metal cation, $\mathrm{Fe}^{+} \mathrm{C}_{6} \mathrm{~F}_{4} 1$. The metal distonic ion structure of this ion was demonstrated by ion-molecule reactions and collisioninduced dissociation. Fluorine substitution on the benzene ring facilities iodine atom migration by the strong inductive withdrawal of electrons and forming the $\mathrm{d} \pi$-p $\pi$ bond. However, the non-fluorine-substituted metal ion, $\mathrm{Fe}^{+} \mathrm{C}_{6} \mathrm{H}_{4} 1$ does not rearrange to the rnelal distonic ion structure. Nascent metal distonic ions, $\mathrm{Fe}^{+} \mathrm{C}_{6} \mathrm{~F}_{4}{ }^{\circ}$ and $\mathrm{Fe}^{+} \mathrm{C}_{6} \mathrm{~F}_{4}{ }^{\circ}$, rearrange to linear diyne-ene structures through metal biradical para-benzyne as intermediates. The study of novel transition-metal distonic ions reveals a whole new area of organometallic ion chemistry.

\section{$\underline{\text { Publications }}$}

1. $\mathrm{CoCF}_{3}{ }^{+}$is Really $\left(\mathrm{FCo}^{+}--\mathrm{F}_{2} \mathrm{C}\right)$. Chen, Q.; Lin, C.-Y.; Chen, H.; Freiser, B. S. Organometallics 1997, 16, 4020-4022.

2. Observing Unimolecular Dissociation of Metastable Ions in FT-ICR: A Novel Application of the Continuous Ejection Technique. Lin, C.-Y.; Chen, Q.; Chen, H.; Freiser, B. S. J. Phys. Chem. A 1997, 101, 6023.

3. Gas-Phase Reactions of $\mathrm{FeCH}_{2} \mathrm{O}^{+}$and $\mathrm{FeCH}_{2} \mathrm{~S}^{+}$with Small Alkanes: An Experimental and Theoretical Study. Chen, Q.; Chen, H.; Freiser, B. S. J. Am. Chem. Soc. 1997, 119, 12879.

4. Bond Dissociation Energy Determinations for $\mathrm{MOC}\left(\mathrm{CH}_{3}\right)_{2}{ }^{+}$and $\mathrm{MOD}\left(\mathrm{CD}_{3}\right)^{+}$, $(\mathrm{M}=\mathrm{Cr}, \mathrm{Mn})$, using the Continuous Ejection and Radiative Association Methods. Lin, C.-Y.; Chen, Q.; Chen, H.; Freiser, B. S. Int. J. Mass Spectrom. Ion Process. 1997, 167/168, 713.

5. Coupling Reactions of $\mathrm{Fe}(\text { Benzyne })^{+}$and $\mathrm{Fe}(\text { Naphthyne) })^{+}$in the Gas-Phase. Kan, S. Z.; Xu, Y. C.; Chen. Q.; Freiser, B. S. J. Mass Spectrom. 1997, 32, 1310.

6. Density functional studies of the potential energy surface of the $\mathrm{Ni}^{+}\left(\mathrm{CF}_{3}\right)$ complex. Chen, Q.; Freiser, B. S. Chem. Phys. Lett. 1998, 284, 339.

7. Experimental and Theoretical Studies of $\mathrm{MCF}_{3}+(\mathrm{M}=\mathrm{Fe}$ and $\mathrm{Co})$ : Reactivities, Structures, and Potential Energy Surface for C-F Activation. Chen, Q.; Freiser, B. S. J. Phys. Chem. A 1998, 102(19), 3343. 
8. Reactions of $\mathrm{FeCF}_{2}{ }^{+}$and $\mathrm{CoCF}_{2}{ }^{+}$with simple alkanes and olefins in the gas phase: an FTICR and density functional study. Chen, Q.; Auberry, K. J.; Freiser, B. S. Int. J. Mass Spectrom. Ion Process. 1998, 175, 1.

9. Generation, Characterization and Reactivity of the Transition Metal-obenzyne analog of Pyrazine (Fe+-2,3-didehydropyrazine) in the Gas Phase: An Experimental and Theoretical Study. Chen, H.; Jacobson, D. B.; Freiser, B. S. Organometallics, 1999, 18, 1774.

10. Interconversion of $\mathrm{Fe}\left(\mathrm{C}_{2} \mathrm{H}_{3}\right)^{+}$and $\mathrm{HF}_{2}\left(\mathrm{C}_{2} \mathrm{H}_{2}\right)^{+} ; \mathrm{An}$ FTYCR and Density Functional Study. Chen, H.; Jacobson, D. B.; Freiser, B. S., Submitted to Organometallics.

11. Structure and reactivity studies of $\mathrm{CoHNO}^{+}$in the gas phase. $\mathrm{Chen}, \mathrm{H}$; Jacobson, D. B.; Freiser, B. S., Submitted to J. Phys. Chem. A. 